УДК 550.34

O. Chalyi , Geophysicist M. Diaconescu ${ }^{2}$, Researcher

I. Gurova ${ }^{1}$, Senior Researcher Y. Lisovyi ${ }^{1}$, Researcher P. Pigylevsky ${ }^{1}$, Dr. Sci. (Geol.), Senior Researcher S. Shcherbina ${ }^{1}$, PhD (Phys.-Math.), Senior Researcher A. Shevtsov ${ }^{3}$, Researcher L. Shumlianska ${ }^{1}$, PhD (Geol.), Junior Researcher ${ }^{1}$ Institute of Geophysics, National Academy of Sciences of Ukraine,
32 Palladina Ave., Kyiv, 03860, Ukraine
${ }^{2}$ National Institute for Earth Physics, Magurele, Romania ${ }^{1}$ Institute of Geophysics, National Academy of Sciences of Ukraine,
32 Palladina Ave., Kyiv, 03860, Ukraine
${ }^{2}$ National Institute for Earth Physics, Magurele, Romania ${ }^{3}$ Dragomanov University, Kyiv, Ukraine

\title{
THE CAUSE OF HIGH INTENSITY OF SEISMICITY IN UKRAINE
}

\begin{abstract}
(Рекомендовано членом редакційної колегії д-ром геол. наук О.І. Меньшовим и чл.-кор. НАН України О.В. Кендзерою)
In the article, the earthquake near Sumy is considered in detail. According to the authors, this earthquake occurred under the influence of several stress regimes. At the regional level: it is related to the transfer of stresses from the Vrancea zone along the mantle lineament of Sollogub; a change in the local stress field, which is created by blocks with different thicknesses of the earth's crust, with the presence of subcrustal thermal anomalies. The area of the location of the earthquake focus near the town of Sumy in tectonic terms is on the southwestern slope of the Voronezh crystalline massif near the northeastern side of the Dnieper-Donets Basin (DDB). The epicenter is confined to the northern extension of the Krivyy-Rig-Kremenchug suture zone. The earthquake focus is confined to the tectonic node formed by the eastern edge fault of the Krivyy-Rig-Kremenchug suture zone and the northern side fracture of the DDB. The main deep faults near the source of the earthquake are the northern side fault of the DDB rift and the northern extension of the Krivyy Rig-Kremenchug fault. The hypocenter of the event is in the area with sharp change in the structural plan of the Moho surface accompanied by a negative mantle gravitational anomaly. In the relief of the Moho surface, a superimposition of the structural plan of the northwestern direction, connected with the Devonian rift of the DDV, on the ancient structural plan of the Ukrainian shield and Voronezh crystalline massive is clearly visible. Within the DDV, the isohypses of the Moho surface clearly delineate the ascent to $\sim 35 \mathrm{~km}$ in the central part of the rift. The Krivyy-Rig-Kremenchug suture zone is expressed in the Moho surface by a narrow elongated depression with depths of more than $50 \mathrm{~km}$ in the central part. Here, in the lower part of the cortex, the development of the crust-mantle mixture is observed. The Krivyy-RigKremenchug suture zone is also distinguished by the development of high-intensity deep magnetic inhomogeneities along it. In addition, here in the lower part of the crust and in the upper mantle a linear object of high electrical conductivity is isolated. Thus, the earth's crust of the region has a pronounced physic-geological heterogeneity, which creates instability of lithostatic stress, and this, in turn, is a prerequisite for the appearance of additional stresses.

Keywords: deep fault, mantle fault, magnitude, earthquake, intensity, Vrancea.
\end{abstract}

Introduction. The heterogeneity of the lithosphere is an important source of the local stress system. Local stress system being under the influence of regional and supraregional stress systems can come to an unstable state, which is reflected in the activation of seismic processes.

The internal additional stresses resulting from the heterogeneity of the geological environment are distributed unevenly in volume, but in accordance with the heterogeneity of the structure of the earth's crust. Local regions of increased stresses of different scales are formed. Discharge of stresses also occurs discretely and is determined by the nature of the setting structure.

Stresses and deformations of the crust are determined mainly by the regional properties of the setting, the type of deformation mechanism, and the structural features of this section of the crust: the presence of inhomogeneities of various nature and different scales (discontinuities, stratification, blockiness, and various inclusions) in it.

The greatest attention in studies of local stress fields is given to the precisely those local stress fields that are formed in a heterogeneous medium under the influence of regional stresses. At the same time, physico-geological heterogeneities in the structure of the earth's crust and the upper mantle can themselves be sources of considerable stresses and create their own local fields that substantially alter and complicate the stress system in a particular section of the earth's crust.

Local additional stresses can be created by such factors as:

- the relief load or abnormal density of the overlying layer, under the influence of loads of the overlying layer with anomalous density, the underlying layer tends to "spread out";

- a difference in the thickness of the earth's crust create additional stresses, the average value of the additional stresses due to variations in power equals the additional load. The difference in the thickness of the earth's crust of 5 $\mathrm{km}$ at a constant density of the crust can create additional stresses, which can cause an earthquake of magnitude more than 5 (Leonov, 1995)

- the erosion process, which changes the thickness of the upper sedimentary layer, and changes the existing stress fields;

- local disturbances of isostasy and its restoration, heterogeneous geological environment constantly tends to isostatic equilibrium at various levels in the lithosphere, for example, the effect of isostasy on local seismicity after melting of the ice sheet on the Scandinavian Peninsula is well studied (Fjeldskaar et al., 2000);

- physico-chemical processes, accompanied by a change in volume and mass transfer.

Analyses of factors affect the seismicity of the territory of Ukraine. V.B. Sollogub (Sollogub 1986) wrote about the surface of the asthenosphere that has a north-east direction and attributes to extension that propagated about 200-250 kilometers from Bucharest to Khar'kiv. This lithosphere avlakogene is limited by mantle lineaments in the same direction (Fig. 1, 2). This structure passes through the whole territory of Ukraine in south-western direction to Vrancea zone and on this structure several strongest earthquakes on territory of Ukraine (Krivyy Rig, Sumy region) and Romania are localized. These earthquakes were thoroughly investigated by means of instrumental and macroscopic methods. During the current research, it was revealed that the intensity and position of the epicenters indicate the necessity to use the uninterrupted regime of observation for locations of earthquakes. Earthquakes in these regions are not only very interesting from the viewpoints of science, but they can represent a threat to the safety of local people. Subject of our research in this article is important for understanding the stress regime interaction of tectonic processes that develop in the Dnieper-Donetsk basin and the Ukrainian shield with strong earthquakes on the territory. 


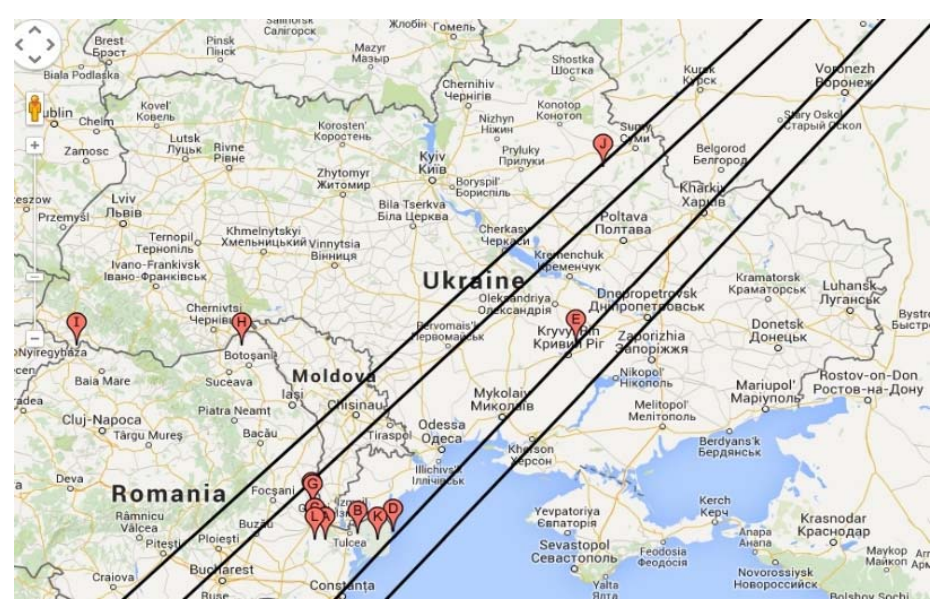

Fig. 1. The mantle lineaments (Соллогуб, 1986) that pass through Sumy area and seismic active zone Vrancea with epicenters of Ukrainian and Ukrainian-Romanian earthquakes for last five years

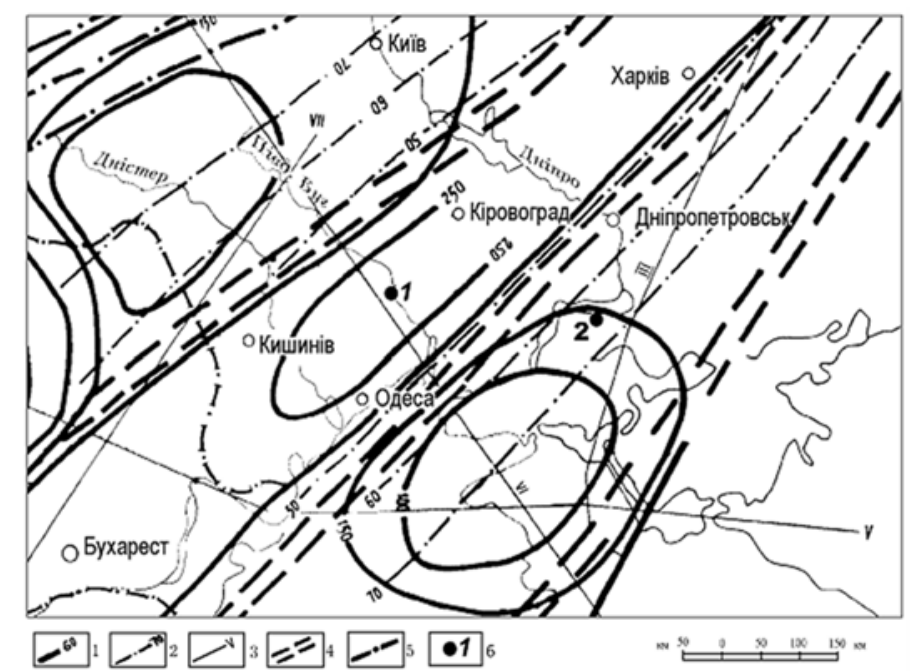

Fig. 2. Block diagram of the upper mantle according to the DDD (Соллогуб, 1986):

1 - asthenosphere surface contour line, $\mathrm{km} ; 2$ - surface layer with low velocity in the upper mantle, km; 3 - DDD profiles; 4 - mantle lineaments north-east, 5 - mantle lineaments; 6 - nuclear stations (1 - South-Ukrainian, 2 - Zaporizhia)

One of the most probable causes of earthquakes on our territory is the presence of an active form of neotectonic movement of deep faults in crust and under crust mantle on territory of Ukraine. The reason for the growth of seismicity is probably connected with some serious global problems. One from is based on increasing of the world annual average temperature (Fig. 3).

It is the greenhouse effect by which the Earth's atmosphere keeps the heat received from the Sun and it is increasing due to emissions of industrial and agricultural enterprises (Fig. 4).

The growing of the average value of the temperature may produce the significant influence on seismic activity of the Earth owing to the influence on thermodynamics conditions in the mantle especially on its subsurface part lithosphere containing almost all seismic tremors events. Fig. 5 shows the histogram with all world seismic events from 2011 till now with magnitudes from 0.0 to 9,9 . If the first maximal value of the quantity world's earthquakes coincides with activity of the Sun (especially from 2014-02-01 to 201406-30), second maximal values have grown from second part of 2016 till now (Fig. 5). It is preliminary compared by an empirically approach only, because it requires an additional investigation.

Two significant dangerous natural processes, that are: growing of a global mean surface temperature (Fig. 3) and global seismic activity (Fig. 5) make us scientifically worry about local seismicity in our country and about near areas -
Romania, Poland and Russia (Caucasus). There is a real evidence of the influence of the growing global mean surface temperature on tectonic structure of the Earth that may produce a new type of seismic events that may have a form of records as nuclear explosions (National Centers for Environmental Information, n.d.).

The growing worldwide seismicity may have weak influence on seismicity in Ukraine because, as we know, this country is basically placed on stable tectonic structure of Ukrainian shield. For preliminary estimation a level of seismic activity must be viewed to analyze some seismic records of Ukrainian earthquakes that happened. For this preliminary empirical analyzing we used the graph of seismic intensity that was taken from EMSC world seismic data, Real Time Seismicity of the European-Mediterranean Seismological Centre from November 2004 to April 2017 year (European Mediterranian Seismological Center, n.d.).

The dynamics of seismic process on territory of Ukraine may be interpreted as unstable because the level of this process is significantly random (Fig. 6). The high level of the randomity of this local process is based on absent of active subduction zones which may be found in active tectonic areas of the Indonesia or Southern America, for example. The value of Ukrainian earthquake's quantity achieved the maximum in period of time between 2011 and 2015 (Fig. 6). This level of maximal val.square (50px) may be based on interaction of global seismicity process and 11-year activity of the Sun (Shcherbyna, 2013). 


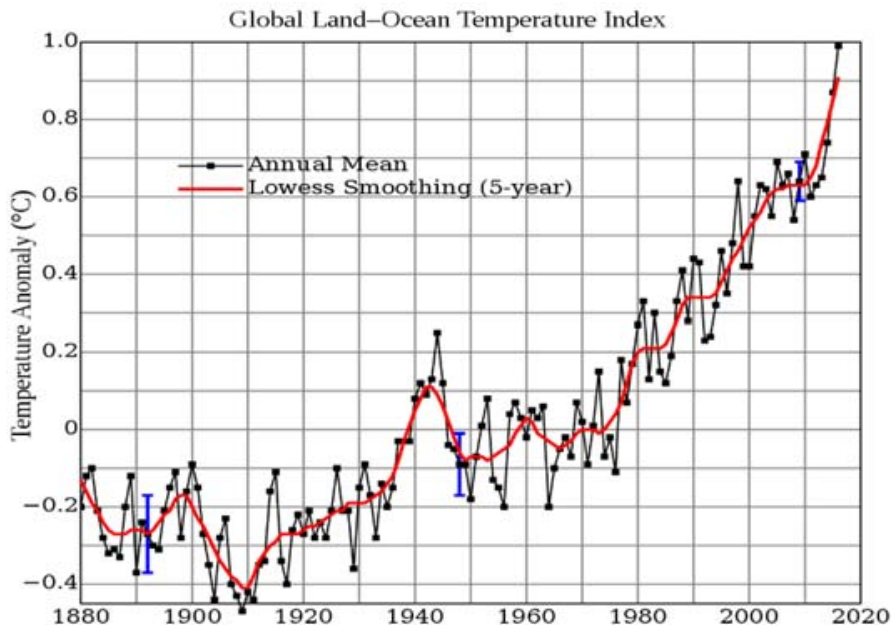

Fig. 3. Global mean surface temperature change from 1880 to 2016 , relative to the $1951-1980$ mean (Temperature record, n.d.)

Land \& Ocean Temperature Departure from Average Jan 2014 (with respect to a $1981-2010$ base period) Data Source: GHCN-M version 3.2 .2 \& ERSST version 3

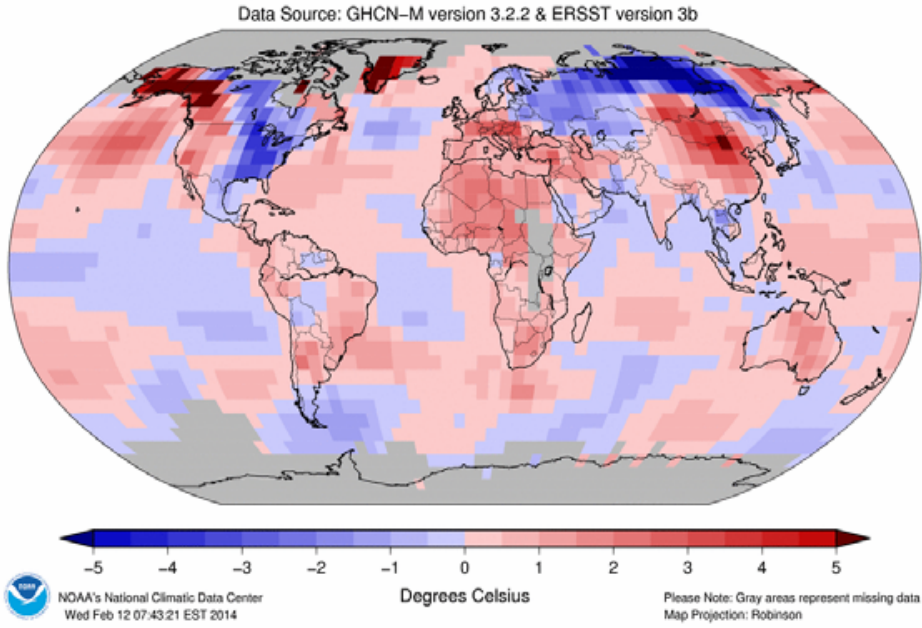

Fig. 4. In the atmosphere, seas and around the poles - everywhere on the Earth's climate reached alarming new levels (Temperature record, n.d.)
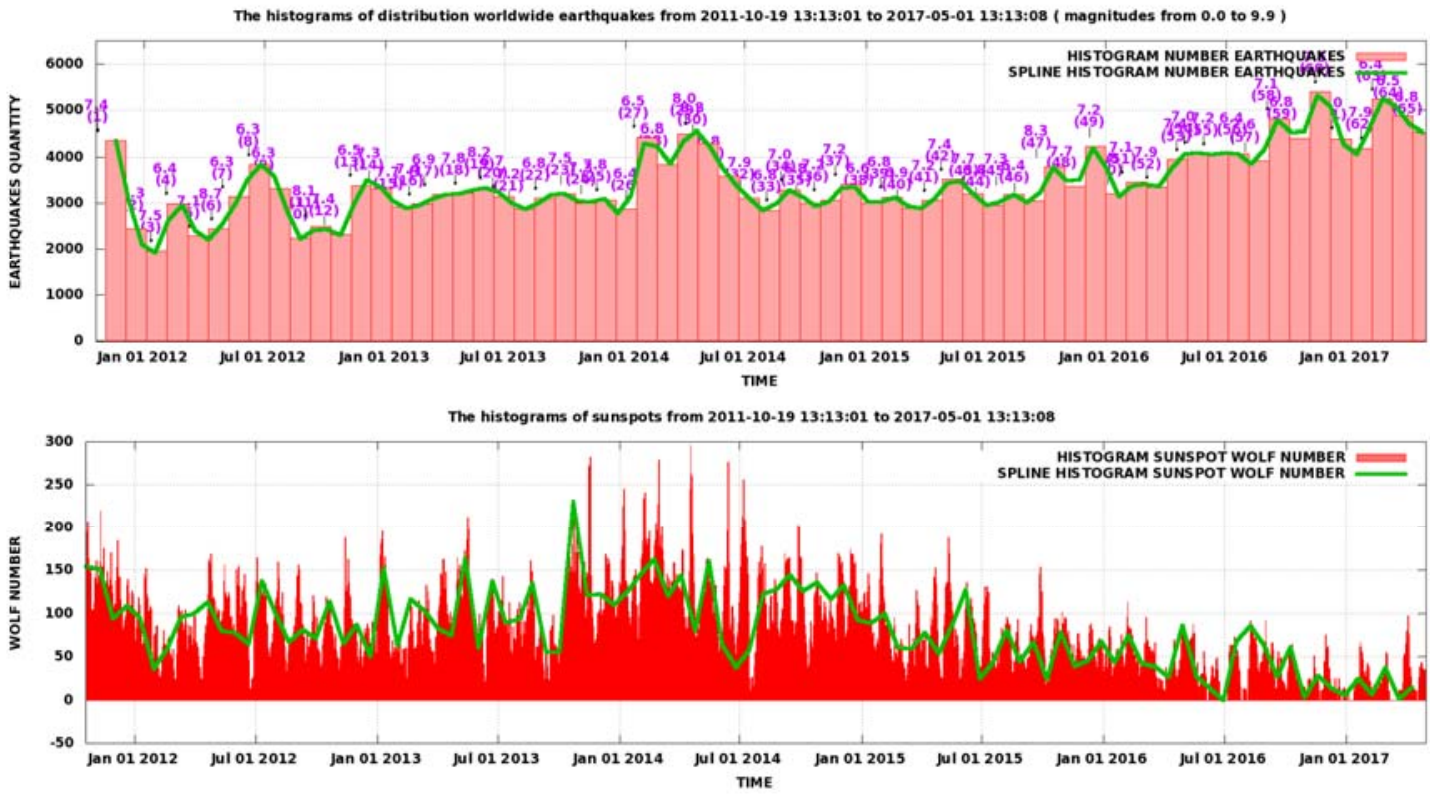

Fig. 5. The global seismic activity of the Earth from October 2011 to May 2017.

Top - histogram of the earthquakes quantity, bottom - Wolf number. Relationships between all earthquakes and sunspot number from: 2011-10-19 to: 2017-05-01 (Temperature record, n.d.) 


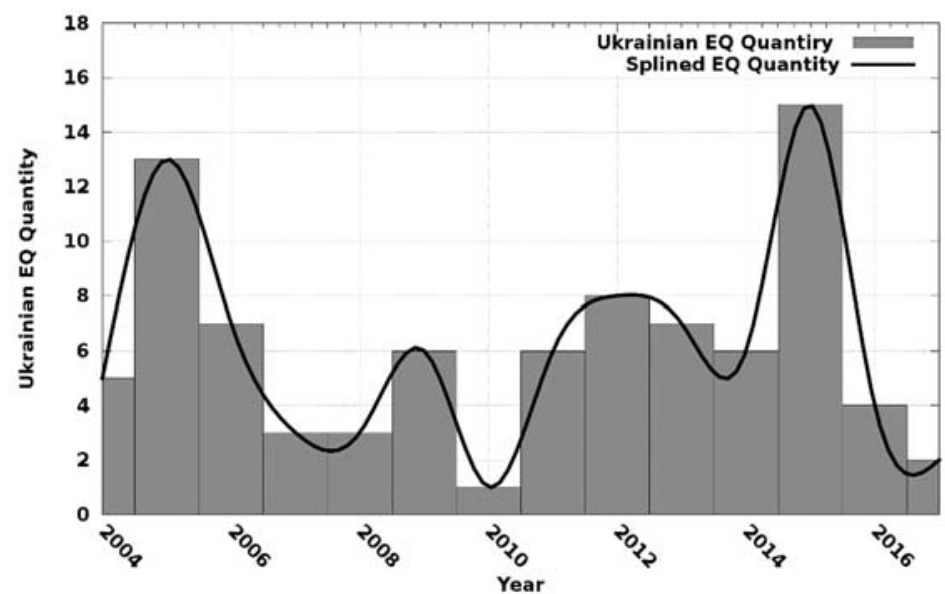

Fig. 6. The temporal distributions of the quantity Ukrainian earthquakes by years from November 2004 to April 2017

The global map of these seismic events shows (Fig. 7) that the basic part of them is placed in Carpathian area that is nearer to Vrancea active tectonic structure. Other parts of this seismic area are distributed in active or passive zones that are near to Romania-Odessa region, Crimea Region, Caucasus Region, Sumy area, Krivyy Rig area and Mariupol' area. There is one earthquake that may be viewpointed from our preliminary hypothesis and may have a direct relation with Romanian seismic active zone Vrancea. The earthquake that happened on 03 February 2015 in hypocenter that is near to town Sumy in North of Ukraine (Shumlianska et al., 2015)
(Fig. 7). The coordinates of the epicenter were obtained, as well as the depth of the source. The calculated depth of the hypocenter $54 \mathrm{~km}$ was verified in several ways: the deep phases $\mathrm{pP}, \mathrm{sP}$ were identified for remote stations; a direct kinematic problem was calculated for Poltava station for two different depths of the earthquake focus of 10 and $54 \mathrm{~km}$. It is shown that the best result is a solution with a depth of $54 \mathrm{~km}$. This depth of the focus refers to the zone of the depth difference of the Moho surface, as well as the gradient zone of the temperature anomaly - an unstable zone where additional stresses appear.

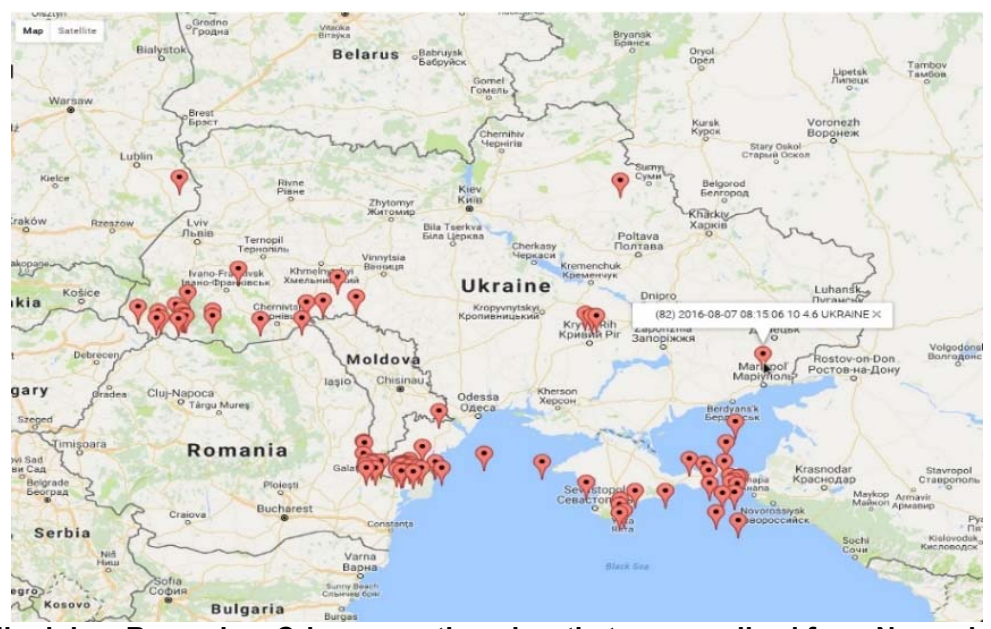

Fig. 7. The map of Ukrainian, Romanian, Crimean earthquakes that were realized from November 2004 to April 2017 with magnitudes from 0 to 6 . Sumy's earthquakes is on top point of the map

After common analyzes for spatial distribution, all Ukrainian earthquakes must be tested out with other variants of investigations related with dedicated energy. As we don't know the real nature of these random seismic events, several attempts to study the energy of these events with different parameters must be carried out. These preliminary parameters may be taken from all group parameters of the basic seismic event's parameter logarithm of energy that is reflected as magnitude. We will not concentrate our attention on this research of different types of these parameters (Mv, Ml, Mr, etc.) and they all will be concatenated into one common parameter of the energy of seismic events as some common $M$ as a common magnitude. Next important step for this research is to use a different type of difference between studying magnitudes $M$ because the seismicity of Ukrainian shield is not very active.

For this in our first simple researching were used two values of the steps for calculated magnitudes $-0,1$ and 0,5 . First variant with value of delta magnitude 0,1 is imperfect for suitability for significant values of the earthquake's energy but it must be used for passive Ukrainian tectonic area. Second variant of the value that is equal to 0,5 is physically based on this number because the exactness of this parameter is included in its numerical interval.

After using a special system with database MySQL for collection and mathematical and statistical testing of any seismic events we received necessary results that are presented on Fig. 8 and Fig. 9. Second variant of the value that is equal to 0.5 is physically based on this number because the exactness of this parameter is included in its numerical interval.

Fig. 8 shows common energy for last Ukrainian earthquakes from November 2004 to April 2017 and is divided into three independent energy groups. First group is between 2,0 and 3,0 values of the magnitude, second group has interval from 2,5 to 3,5 and last group is included in interval from 3,0 to 4,0 . To search the answers to these questions about availability of three groups for Ukrainian 
earthquakes energy we need to do an additional researching for explaining these questions. For simpler explaining of this question the comparative analysis analogical data with other step for dividing by magnitudes may be produced. Fig. 9 shows the result of this preliminary investigation.

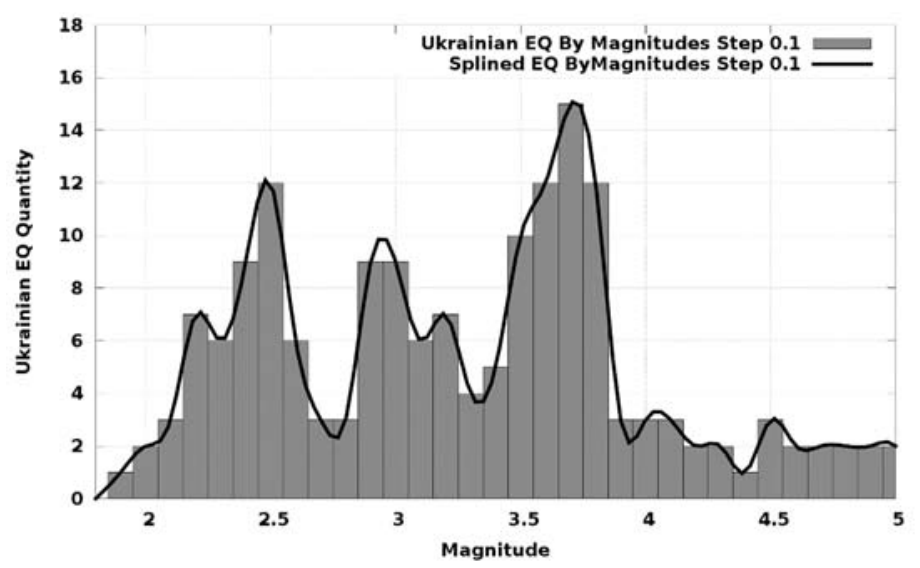

Fig. 8. The histogram for values of the magnitudes $M$ for all Ukrainian earthquakes divided on several groups with step 0,1

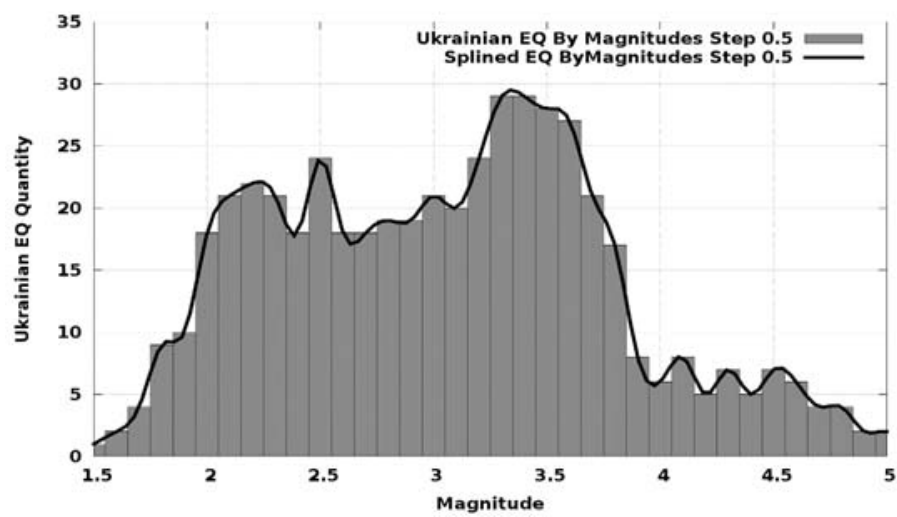

Fig. 9. The histogram for values of the magnitudes $M$ for all Ukrainian earthquakes divided on several groups with step 0,5

After selecting Ukrainian earthquakes from special MySQL database for last fifteen years and preliminary analyzing of all selected data with different parameters it was found out that the basic group of Ukrainian and around territories earthquakes are placed in basic energy area of magnitudes with minimal and maximal values 2,0 and 4,0 respectively. Two groups were selected, with maximal and minimal values of the magnitude being in confidential interval and allowing us to use them effectively.

Sumy's Earthquake and the Seismicity in Ukraine. The area of the location of the earthquake focus near the town of Sumy in tectonic terms is on the southwestern slope of the Voronezh crystalline massif near the northeastern side of the DDB. The epicenter is confined to the northern extension of the Krivyy-Rig-Kremenchug suture zone. The earthquake focus is confined to the tectonic node formed by the eastern edge fault of the Krivyy-Rig-Kremenchug suture zone and the northern side fracture of the DDB.

The main deep faults near the source of the earthquake are the northern side fault of the DDB rift and the northern extension of the Krivyy Rig-Kremenchug fault.

The hypocenter of the event in the area with sharp change in the structural plan of the Moho surface occurs accompanied by a negative mantle gravitational anomaly. In the relief of the Moho surface, a superimposition of the structural plan of the northwestern direction, connected with the Devonian rift of the DDV, on the ancient structural plan of the Ukrainian shield and Voronezh crystalline massive is clearly visible. Within the DDV, the isohypses of the Moho surface clearly delineate the ascent to $\sim 35 \mathrm{~km}$ in the central part of the rift. The Krivyy-RigKremenchug suture zone is expressed in the Moho surface by a narrow elongated depression with depths of more than
$50 \mathrm{~km}$ in the central part. Here, in the lower part of the cortex, the development of the crust-mantle mixture is observed. The Krivyy-Rig-Kremenchug suture zone is also distinguished by the development of high-intensity deep magnetic inhomogeneities along it.

In addition, here in the lower part of the crust and in the upper mantle a linear object of high electrical conductivity is isolated. The authors (Gordienko et al., 2004) associate it with high fluid saturation due to thermal dehydration of rocks. A high-intensity horizontal temperature gradient is observed here, as well as a change in the magnetic and electrical properties of the rocks of the lower crust and upper mantle, which creates favorable conditions for the discharge of accumulated energy in the form of an earthquake.

Thus, the earth's crust of the region has a pronounced physic-geological heterogeneity, which creates instability of lithostatic stress, and this, in turn, is a prerequisite for the appearance of additional stresses.

The results of this researching are dedicated to the cause of the earthquake that happened in Ukraine very near to the city Sumy on 03.02.2015 5:56 GMT. The aim of this article is to focus on the fact that the Ukrainian earthquake near to Sumy is a natural seismic event associated with stress regime in deep faults and mantle lineaments that extend from Vrancea zone to Voronezh crystalline massive. In the studying of powerful Ukrainian and Romanian earthquakes with magnitudes between 3.9 - 4.6 that occurred before the earthquake in Sumy was revealed, they are all interconnected by a common fault system (Gordienko et al., 2004) (Fig. 1).

A preliminary analysis of Seismic Records. The seismic event in Sumy with magnitude 4,6 that happened on 03 February 2015 by GMT time 05:56:31 in epicenter with 
coordinates $50.64 \mathrm{~N} 34.13 \mathrm{E}$ may be viewed through short preliminary analyzing of seismic records that were fixed on many seismic stations. By form of the records of this extraordinary event, it is possible to discuss and understand the sense - why it happened. Many zones of northern part of Ukraine having the areas where many technical explosions happened are intended for extraction of natural products from quarries (The map of technical explosions on North of Ukraine, 2011). Below are presented several basic forms of seismic records that were received from the following seismic stations: UZH - Uzgorod, MEZ - Mezgyria, LVV - Lviv, UK15 - Krivyy Rig.

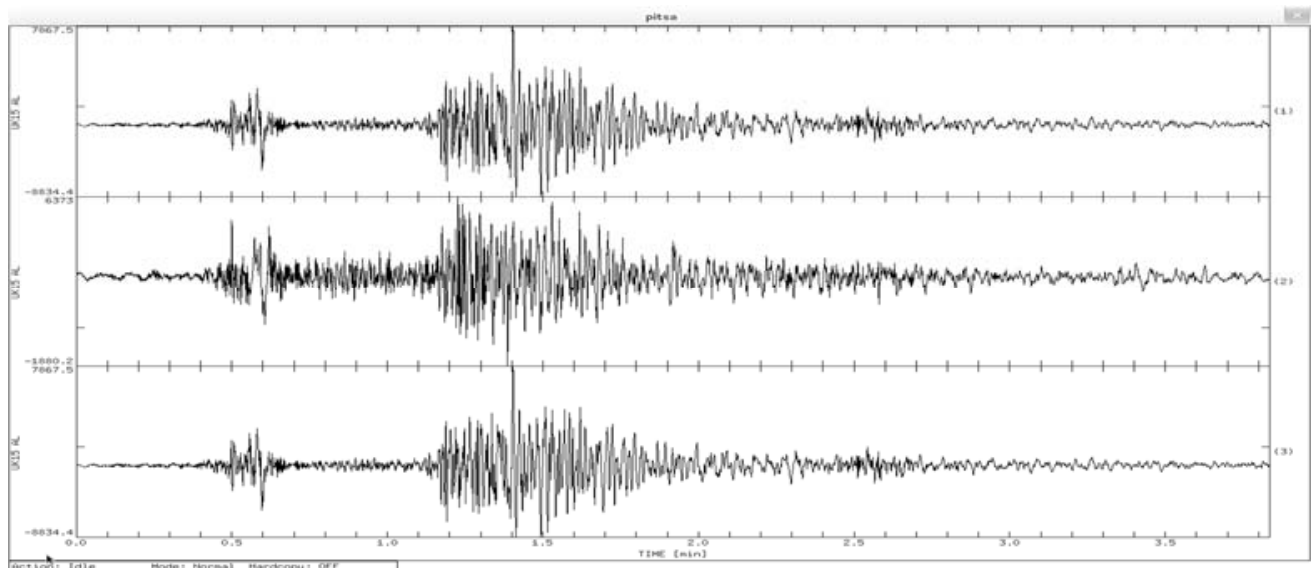

Fig. 10. The filtered three-components seismic record station UK15 (Krivyy Rig) of the earthquake in Sumy that happened by GMT time at 03 February 2015 05:56:31

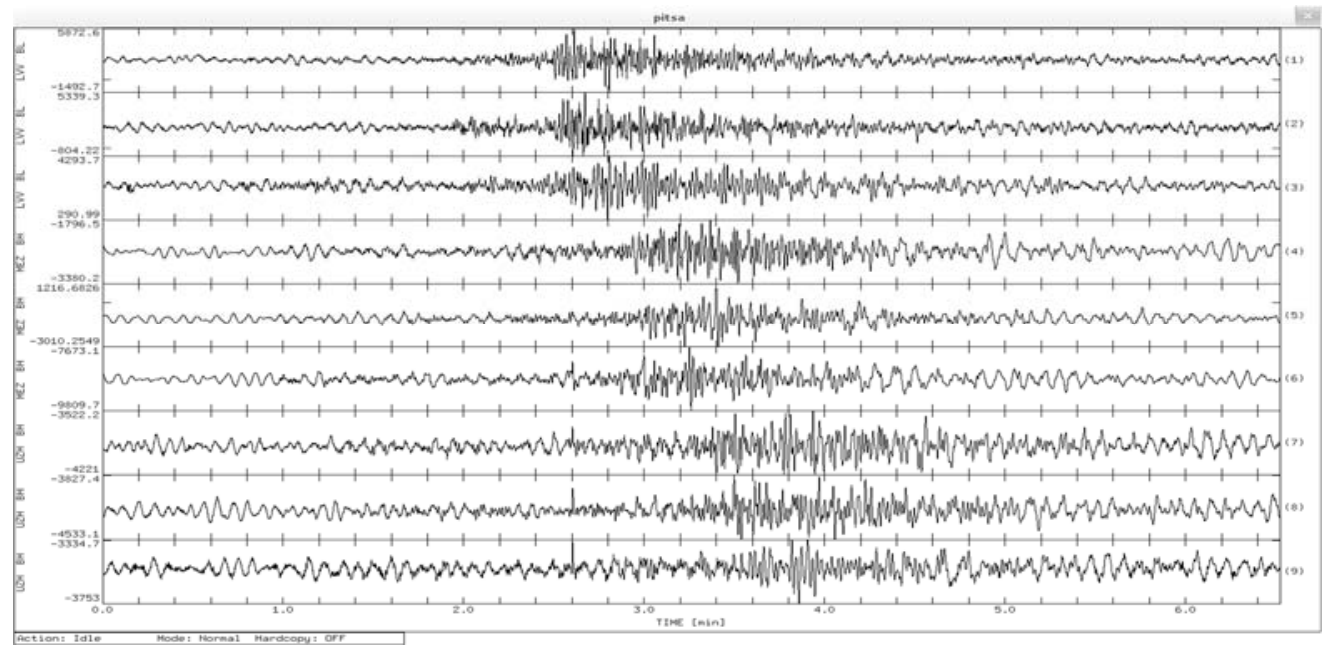

Fig. 11. The filtered three-components seismic records received from stations Carpathian and Transcarpathia regions: LVV (Lviv), MZH (Mezegirja), UZH (Uzhorod) of the earthquake in Sumy that happened by GMT time at 03 February 2015 05:56:31

The magnitude of this seismic event that is equal to 4,6 , is too big for technical TNT explosion. Preliminary viewing analysis of records (Fig. 10, 11) has shown that the distance between epicenter of seismic event in Sumy and stations of Carpathian and Trans-Carpathian regions is very big for ordinary explosions. For final evidence of the nature of this seismic event in Sumy there must be produced the calculation and analyzing of a mechanism of geotectonic structure of the source of tectonic block that generated this event how it was made for earthquake in Krivyy Rig (Hrytsay et al., 2013).

More evidence that it is real seismic event (not strong explosion) is presented on Fig. 10, 11. The clear first part of these records consists of two subgroups of records that may be interpreted as $\mathrm{Pg}$ and $\mathrm{Sg}$ variants of two first arrived waves that are widely known and are often used for the processing of local seismic events. Last third arrived wave may be interpreted as a $\mathrm{Lg}$ wave that has a classic form of its part what may especially be seen on records of stations LVV (Lviv), MZH (Mezigirja), UZH (Uzhorod) (Fig. 11).

Next attempt for understanding the nature of strong Ukrainian earthquake is the estimation of the length by time between primary Pg wave and secondary Sg wave. After calculation of this temporal value it was found out that it equals about one minute ( 60 seconds).

Temporal value of dT that was calculated as a difference between $\mathrm{Pg}$ and $\mathrm{Sg}$ waves points that this seismic event is not a technical strong explosion (Walter et al., 2011). The final statistical calculation of the coordinates of this seismic event in different international organization has given the following geographical values of longitude and latitude by EMSC - 34,13E, $50,64 \mathrm{~N}$, by GSPC - 34,20E, 50,48N. Table1 presents all last calculated geographical data that had been gotten in NCSD IGPH NAS Ukraine (Kyiv). For this calculation there were used the results of detection parameters of seismic event by three components records that had been received from two stations - MLR (Romania) and UK15 (Ukraine).

After calculating the mean values (MV in Table 1) of geographical coordinates that are presented in Table 1, numerically estimations of statistical errors of these mean values were calculated. The calculated mean values and estimation of their statistical errors are as follows:

1) by records of the Romanian seismic station MLR latitude 50.544 $\pm 2.5 \mathrm{E}-04$, longitude $33.915 \pm 0.0 \mathrm{E}-04$; 
2) by records of the Ukrainian seismic station UK15 latitude $50.529 \pm 5.0 \mathrm{E}-04$, longitude $34.093 \pm 2.5 \mathrm{E}-04$;

2) by records of the Ukrainian seismic station UK15 latitude $50.529 \pm 5.0 \mathrm{E}-04$, longitude $34.093 \pm 2.5 \mathrm{E}-04$;
Calculated the middle values of the geographical coordinates the seismic event and their statistical estimations had shown that we may trust to these values.

The coordinates of the seismic event near Sumy calculated as middle values for statistical estimation

\begin{tabular}{|c|c|c|c|c|}
\hline \multirow{2}{*}{$\mathbf{N}$} & STATION MLR (Romania) & \multicolumn{2}{c|}{ STATION UK15 (Ukraine) } \\
\cline { 2 - 5 } & Longitude & Latitude & 34.109 & Latitude \\
\hline 1 & 33.856 & 50.605 & 34.050 & 50.527 \\
\hline 2 & 33.739 & 50.630 & 34.117 & 50.530 \\
\hline 3 & 34.013 & 50.486 & 34.097 & 50.539 \\
\hline 4 & 34.052 & 50.456 & $\mathbf{3 4 . 0 9 3}$ & 50.518 \\
\hline MV & $\mathbf{3 3 . 9 1 5}$ & $\mathbf{5 0 . 5 4 4}$ & $\mathbf{5 0 . 5 2 9}$ \\
\hline
\end{tabular}

Final conclusion - What we should wait and do. We showed connection between mantle lineaments (Sollogub, 1986) and deep faults on territory of Ukraine and earthquakes that occurred in those places (Fig. 1, 2). These earthquakes are concentrated within these lithosphere heterogeneities. The earthquake in Sumy region illustrates Sollogub's assumptions. Given the geological and tectonic structure within the Dnieper-Donets basin, an earthquake in the area could occur with very low probability. Since we know that the earthquake in Sumy focuses on node of several crust faults and mantle lineament, and the earthquake in Krivyy Rig is also located on the fault and mantle lineament, it could mean the area of unstable condition and area of concentration of stress field to spread not only in crust and upper mantle too. Both lithosphere heterogeneities have the same direction, which connect seismic active zones - Ukrainian (Sumy, Krivyy Rig) and Romanian (Vrancea zone). They have a common breaking line, common heterogeneities which produce unstability in lithosphere and can potentially harm. Sumy earthquake occurred at the zone of Dnieper-Donetsk paleoryft and Voronezh crystalline massive junctions, which are directly near one of the possible seismogenic zone and it was referred earlier in the article of A.A. Tripolskiy (Tripolskiy et al., 2012).

Earthquakes in Krivoy Rog and Sumy region are characterized by seismic activity with the same magnitude and showed the displacement of the Krivyy-RigKremenchug fault at left, as it was evidenced by the data processing of earthquakes waveforms records. Hypocenters of the earthquakes are likely to be placed along crossing zone (nodes) with mantle faults on V.B. Sollogub's map (Sollogub, 1986). These areas correspond to stressdeformation processes which act in the crust of the Ukraine and Romania. The analyzing of the available geophysical information and images in Fig. 1, 2 and 7 allows admitting the fact that the occurrence of these earthquakes suggests possible global seismological problem for Ukraine and Romania which is in active form now. Thus, the area of intersection of faults mantle zone of the Krivyy-RigKremenchug suture zone may be characterized in the future as increased level of seismicity. In addition, the earthquake that is located in the common area of the north-eastern side of the southern slope of the Voronezh crystalline massif (Kendzera et al., 2016), allows expecting the growing of seismic activity that may be much higher in comparison to the south-western side. With considering of the registration of the earthquake that took place on 03-02-2015 the assumption of the possible increasing of seismic activity in the general area of Romania has proved justified, which undoubtedly increases the future credibility to this hypothesis.

Thus, a brief analysis of geological and geophysical characteristics of the area adjacent to the site of the Sumy earthquake shows that the probability of registration of local earthquakes in the future may be evaluated as high in comparison with neighboring Romanian territories. Romanian earthquake with maximum energy power $(\mathrm{M}=$ $7,0-7,5)$ can lead to the powerful vibrations which will spread over long distances, which will cover the whole Ukraine and tectonic faults extending to Romania (Fig. 1, 2). Thus, the accumulated tectonic energy relaxation will take place, but the effects of shaking with length of about few minutes can cause a considerable damage to the national economy and the people from Romania and Ukraine that have got into the zone of this natural phenomenon.

\section{Список використаних джерел}

Fjeldskaar, W., Lindholm, C., Dehls, J.F., Fjeldskaar, I. (2000). Postglacial uplift, neotectonics and seismicity in Fennoscandia. Quaternary Science Reviews, 1413-1422.

Walter, W.R., Matzel, E., Pasyanos, M.E., Harris, D.B., Gok, R., Ford, S.R. (2011). Empirical observation of earthquakes-explosion discrimination using $\mathrm{P} / \mathrm{S}$ ratios and implications for the source of explosion S-waves. 29-th Monitoring Research Review: Ground-Based Nuclear Explosion Monitoring Technologies, 684-693.

Гордиенко, В.В., Гордиенко, И.В., Завгородняя, О.В., Логвинов, И.М., Тарасов, В.Н., Усенко, О.В. (2004). Геотермический атласс Украины. Национальная Академия наук Украины, Институт геофизики им.С.И.Субботина, Киев.

Грицай, ОД. Гурова, И.Ю Капиниченко, ОА, Малицкий, Д.В., Мила, О.О., Пигулевский, П.И., Ник, С.В. (2014). Исследование природы землетрясений в Кривом-Рогу, 23 июня 2013 г. Материалы научного семинараконференции "Сеймологические и геофизические исследования в сейсмически активных регионах". Львов, 164-170.

Дані температури. (н.р.). Отримано 3 липня 2018, із https://en.wikipedia.org/wiki/Instrumental_temperature_record]

Європейський Середземноморський сейсмологічний центр. (н.р.). Отримано 29 червня 2018, із http://www.emsc-csem.org/Earthquake

Карта техногенних вибухів на півночі України. (2011). Отримано 2 липня 2018, із http://seismo.kiev.ua/GoogleMap/ExplOn2011/

Кендзера, А.В., Трипольский, А.А., Пигулевский, П.Г., Щербина, С.В., Гурова, И.Ю. (2016). Современная сейсмическая активизация Днепровско-Донецкого палеорифта. Доклады НАНУ, 1, 65-70.

Леонов, Ю.Г. (1995). Напряжения в литоссрере и внутренняя тектоника. Геотектоника, 6, 3-21.

Національний центр про довкілля. (н.р.). Отримано 30 червня 2018, із https://www.ncdc.noaa.gov/sotc/global/201401

Новини ВВС Україна (н.р.). Отримано 21 червня 2018, із http://www.bbc.com/ukrainian/news-39341500

Події в космосі та землетруси. (н.р.). Отримано 2 липня 2018, із http://alexars.ru/blizhayshie-kosmicheskie-sobyitiya-i-prohozhdeniekrupnyih-zemletryaseniy-do-12-07-2017-goda/

Соллогуб, В.Б. (1986). Литосфера Украины. Киев: Наук. думка.

Трипольский, А.А., Калюжная, Л.Т., Трипольская, Л.А. (2012). Предсказание возможных сейсмогенных зон в Днепровско-Донецком палеорифте. Геофиз. журнал, 34(1), 95-104

Шумлянская, Л.А., Александров, А.Л. (2016). Землетрясение 3 февраля 2015 г. возле г. Сумы: параметры источника и механизм очага. Сейсмич. приборы, 52(4), 350-359: 350. doi:10.3103/S0747923916040071.

Щербина, С.В. (2013). Динамика солнечных пятен и землетрясения. Второй Всероссийский семинар-конференция "Триггерные эффекты в геосистеме". Москва, 18-21 июля 2013, 112-114.

Щербина, С.В. (2013). Корреляционный анализ взаимосвязей между динамикой солнечной плазмы и процессом генерации землетрясений. $\mathrm{V}$ Международная конференция геофизических технологий предсказаний и мониторинга геологической среды. Львов, 1-4 октября 2013, 370-372.

\section{Reference}

European Mediterranian Seismological Center. (n.d.). Retrieved June 29 2018, from http://www.emsc-csem.org/Earthquake

Fjeldskaar, W., Lindholm, C., Dehls, J.F., Fjeldskaar, I. (2000). Postglacial uplift, neotectonics and seismicity in Fennoscandia. Quaternary Science Reviews, 19, 1413-1422. 
Gordienko, V.V., Gordienko, I.V., Zavgorodnyaya, O.V., Logvinov, I.M., Tarasov, V.N., Usenko, O.V. (2004). Geothermal atlas of Ukraine. National Academy of Ukraine. Institute of geophysics S.I.Subbotina, Kiyv. [In Russian]. Hrytsay, O.D., Gurova, I.Y., Kalinichenko, O.A., Malitsky, D.V., Muila, O.O., Pigulevsky, P.I., Nick, S.V. (2014). Investigation of the nature of the Krivyy-Rig earthquake on June 23, 2013. Materials of the scientific conference-seminar "Seismological and geophysical studies in seismically active regions", Lviv, 164-170. [In Russian]

Kendzera, A.V., Tripolskiy, A.A., Pigulevskyy, P.I., Shcherbina, S.V., Gurova I.Y. (2016). Modern seismic activation of the Dnieper-Donets paleorift. Report of NASU, 1, 65-70. [In Russian].

Leonov, Y.G. (1995) Stresses in the lithosphere and internal tectonics. Geotektonika, 6, 3-21. [In Russian].

National Centers for Environmental Information. (n.d.). Retrieved June 30, 2018, from https://www.ncdc.noaa.gov/sotc/global/201401

News bbc Ukraine. (n.d.). Retrieved June 21, 2018, from http://www.bbc.com/ukrainian/news-39341500)

Shcherbina, S. (2013). Correlation analysis of the relationship between the dynamics of solar plasma and the process of earthquake generation. $V$ International Scientific Conference Geophysical Technologies of Forecasting and Monitoring of the Geological Environment, Lviv, 1-4 October 2013, 370372. [In Russian].
Shcherbina, S. (2013). Dynamics of sunspots and earthquakes. Second All-Russian Seminar-Meeting "Trigger effects in geosystems", Moscow, July 18-21, 2013, 112-114. [In Russian]

Shumlianska, L.O., Aleksandrov, A.L. (2016). The earthquake of February 3, 2015, near Sumy, Ukraine: Source parameters and focal mechanism. Seism. instr., 52(4), 350-359: 350. doi:10.3103/S0747923916040071.

Sollogub, V.B. (1986). Lithosphere of Ukraine. Kyiv: Nauk. dumka. [In Russian].

Space event and earthquake. (n.d.). Retrieved July 2, 2018, from http://alexars.ru/blizhayshie-kosmicheskie-sobyitiya-i-prohozhdenie-

krupnyih-zemletryaseniy-do-12-07-2017-goda /

Temperature record. (n.d.). Retrieved July 3, 2018, from https://en.wikipedia.org/wiki/Instrumental_temperature_record]

The map of technical explosions on North of Ukraine. (2011). Retrieved July 2, 2018, from http://seismo.kiev.ua/GoogleMap/ExplOn2011/

Tripolskiy, A.A., Kalyuzhnaya, L.T., Tripolskaya, V.A. (2012). Forecasting of possible seismogenic zones in the Dnieper-Donetsk paleorift. Geophys. Journal, 34(1), 95-104. [In Russian].

Walter, W.R., Matzel, E., Pasyanos, M.E., Harris, D.B., Gok, R., Ford, S.R. (2011). Empirical observation of earthquakes-explosion discrimination using P/S ratios and implications for the source of explosion S-waves. 29-th Monitoring Research Review: Ground-Based Nuclear Explosion Monitoring Technologies, 684-693.

Надійшла до редколегії 12.04.18

О. Чалий ${ }^{1}$, геофізик

М. Дяконеску², наук. співроб.

І. Гурова ${ }^{1}$, старш. наук. співроб.

Ю. Лісовий ${ }^{1}$, наук. співроб.

П. Пігулевський ${ }^{1}$, д-р геол. наук, старш. наук. співроб.

С. Щербина ${ }^{1}$, канд. геол. наук, старш. наук. співроб.

А. Шевцов ${ }^{3}$, наук. співроб.

Л. Шумлянська ${ }^{1}$, канд. геол. наук, мол. наук. співроб.

${ }^{1}$ Інститут геофізики ім. С.І. Субботіна НАН України,

пр. Палладіна, 32, Київ, 03860, Україна

${ }^{2}$ Національний Інститут Фізики Землі, Магуреле, Румунія

${ }^{3}$ Університет Драгоманова, Київ, Україна

\section{ПРИЧИНА АКТИВНОÏ СЕЙСМІЧНОСТІ В УКРАЇНІ}

Особлива увага у статті приділяється землетрусу, що стався біля міста Суми 3 лютого 2015 р. На думку авторів, цей землетрус відбувся під впливом декількох напружених режимів, пов'язаних на регіональному рівні з перенесенням напруг із зони Вранча вздовж мантійного лінеамента Соллогуба та через зміну локального поля напруги, яке створюється різними за товщиною земної кори блоками за наявності підкорових теплових аномалій і аномалій щільності. Розташування вогнища землетрусу тектонічно приурочено до південнозахідного схилу Воронезького кристалічного масиву біля північно-східного схилу Дніпровсько-Донецького басейну (ДДБ). Гіпоцентр землетрусу розташований в районі з різкою зміною структурного плану поверхні Мохо, що супроводжується негативною мантійною гравітаційною аномалією. У рельєфі поверхні Мохо наочно видно накладання структурного плану північно-західного напрямку, пов'язані 3 девонським рифтом ДДБ на давньому структурному плані Українського щита та Воронезького кристалічного масиву. Ізолінії поверхні Мохо чітко виділяють сходження до 35 км у центральній частині рифта. Криворізько-Кременчуцька шовна зона виражається на поверхні Мохо вузькою витягнутою депресією з глибиною більше 50 км у центральній частині. У нижній частині кори, спостерігається розвиток коро-мантійної суміші, тож земна кора області має яскраво виражену фізико-геологічну неоднорідність, яка створює нестабільність літостатичного тиску, і це, у свою чергу, є передумовою появи додаткових напружень.

Ключові слова: глибинні розломи, мантійні лінеаменти, напруга, землетрус, інтенсивність, Вранча.

О. Чалый ${ }^{1}$, геофизик

М. Дяконеску2, науч. сотр.

І. Гурова ${ }^{1}$, старш. науч. сотр

Ю. Лесовой ${ }^{1}$, науч. сотр.

П. Пигулевский ${ }^{1}$, д-р геол. наук, старш. науч. сотр.

С. Щербина ${ }^{1}$, канд. геол. наук, старш. науч. сотр.

А. Шевцов ${ }^{3}$, науч. сотр.

Л. Шумлянская ${ }^{1}$, канд. геол. наук, мл. науч. сотр.

${ }^{1}$ Институт геофизики им. С.И. Субботина НАН Украины,

пр. Палладина, 32, Киев, 03860, Украина

${ }^{2}$ Национальний Институт Физики Земли, Магуреле, Румыния

${ }^{3}$ Университет Драгоманова, Киев, Украина

\section{ПРИЧИНА АКТИВНОЙ СЕЙСМИЧНОСТИ В УКРАИНЕ}

Особое внимание в статье уделяется землетрясению, произошедшему возле г. Сумы 3 февраля 2015 г. По мнению авторов, это землетрясение произошло под влиянием нескольких напряженных режимов. На региональном уровне они связанны с переносом напряжений из зоны Вранча вдоль мантийного линеамента Соллогуба, а также с изменениями локального поля напряжения, создаваемого различными по толщине земной коры блоками, при наличии подкоровых тепловых аномалий и аномалий плотности. Расположение очага землетрясения тектонически приурочено к юго-западному склону Воронежского кристаллического массива у северо-восточного склона Днепровско-Донецкого бассейна (ДДБ). Очаг землетрясения находится в районе с резким изменением структурного плана поверхности Мохо, что сопровождается отрицательной мантийной гравитационной аномалией. В рельефе поверхности Мохо наглядно видно наложения структурного плана северо-западного направления, связанные с девонским рифтом ДДБ на древнем структурном плане Украинского щита и Воронежского кристаллического массива. Изолинии поверхности Мохо четко выделяют восхождение к 35 км в центральной части рифта. Криворожско-Кременчугская шовная зона выражается на поверхности Мохо узкой вытянутой депрессией с глубиной более 50 км в центральной части. В нижней части коры наблюдается развитие коро-мантийной смеси, поэтому земная кора области имеет ярко выраженную физико-геологическую неоднородность, которая создает нестабильность литостатического давления, и это, в свою очередь, является причиной возникновения дополнительных напряжений.

Ключевые слова: глубинные разломы, мантийные линеаменты, напряжение, землетрясение, интенсивность, Вранча. 